\title{
Improving Financial Marketing And Accountability With Technology Penetration For The Bag SMEs Community In Gresik, Jawa Timur
}

\author{
Yulius Hari \\ Informatics Department, \\ Widya Kartika University, Indonesia \\ Lily Puspa Dewi \\ Informatics Department, \\ Petra Christian University, Indonesia \\ Chitra Santi \\ Economic Department, \\ Widya Kartika University, Indonesia \\ Murpin Josua Sembiring \\ Economic Department, \\ Widya Kartika University, Indonesia
}

\begin{abstract}
Micro and small and medium enterprises (MSMEs) contribute greatly to economic growth in East Java. Around $53.4 \%$ of economic growth comes from MSMEs, most of which are handicraft industries, one of which is a bag and wallet craftsman (Disperindag East Java, 2016). In its development, MSMEs often experience obstacles in adopting a new technology. Gresik is not only known as an industrial area in East Java, but also has a large potential for MSMEs, one of which is bag craftsmen at Ds. Bedilan, Gresik. In line with government programs related to the development of small and medium-sized industries, this community service activity tries to develop capabilities and technology transfer between universities and the community. As a partner in this service activity is a bag craftsman community which is a micro-scale industry. The main problem raised in this activity is the development of marketing by using information technology and improving financial accountability. In the financial problems that often occur in partners is the frequent mix of cash flow of business units with personal and accounts receivable that are often uncollectible. From the results of this activity it can be concluded that partners have a desire to use good technology, but still have not provided positive results for the perception of ease of use.
\end{abstract}

Keywords: Acceptance Model, Technology Diffusion, Perceived ease of use, perceive usefulness.

\section{INTRODUCTION}

East Java is known as the center of Eastern Indonesia, and has a high economic significance, which contributes $14.85 \%$ to the national Gross Domestic Product. The population of East Java in 2010 was $37,476,757$ people, with a density of 784 people / $\mathrm{km} 2$. The regency with the most population in the province of East Java is Malang Regency with a population of 2,446,218 people, while the city with the largest population is Surabaya City with 2,765,487. The population growth rate is $0.76 \%$ per year $(2010)$. 
Meanwhile, for small industry centers and Micro, Small and Medium Enterprises are spread throughout the districts / cities throughout East Java. The number of Micro, Small and Medium Enterprises (MSMEs) in East Java, based on a survey conducted by the East Java Central Statistics Agency (BPS) until the end of 2012, reached no less than 6.8 million MSMEs. The amount is around 50 percent more than the number of MSMEs based on the survey until 2006 which was also conducted by BPS East Java, which reached 4.2 million MSMEs. According to BPS East Java data, the composition of MSMEs engaged in the agricultural sector is 60.25 percent, and the non-agricultural sector is 39.75 percent.

However, with the opening of the Asean Economic Community (MEA) gate at the end of 2015, apparently not all MSMEs in East Java are ready to compete with other countries. The East Java Cooperative and UMKM Office said that only about 3 percent of the total 6.8 million MSMEs in East Java were ready to face MEA. Of that number only 3 percent are ready to face MEA or around 240 thousand middle-class entrepreneurs who have entered the export market. While the small business class of about 5 percent or as many as 400 thousand entrepreneurs are still pioneering exports and still have to be encouraged to be able to compete globally.

The ability to master this technology is becoming increasingly difficult with the large disparity or gap in the ability to adapt technology in society (Caniëls, Lenaerts, \& Gelderman, 2015). The disparity in the ability of technology adaptation between users of technology users in urban areas and rural areas is quite large, especially in communities with weak economic status (Hashim, 2015). This makes the gap between technological capabilities in society (Dahnil, Marzuki, Langgat, \& Fabeil, 2014). On the other hand, the community is required to become more consumerist with the existence of technology but does not have a direct impact on the ability to master the technology.

The lack of innovation and mastery of technology is a major factor in the ability to compete with other industries. So seeing from these problems, it is necessary to have a new breakthrough especially from the university to be able to become a mediator and support for innovation and mastery of technology for MSMEs. In line with government programs related to the development of small and medium-sized industries, Widya Kartika University which has the value of entrepreneurship and is contained in the strategic community service plan, which focuses on the synergy of the development of MSMEs and cooperatives in the community. Answering these challenges in this case trying to accommodate the community service activities, especially in the field of development and utilization of information technology needed to help these MSMEs. The lack of innovation and mastery of technology is a major factor in the ability to compete with other industries (Rahayu \& Day, 2015). So seeing from these problems, it is necessary to have a new breakthrough especially from the university to be able to become a mediator and support for innovation and mastery of technology for MSMEs.

Answering these challenges in this case trying to accommodate the community service activities, especially in the field of development and utilization of information technology needed to help these MSMEs. In this activity two partners were taken as the object of research, both of which were bag crafters in Gresik, East Java. Gresik, East Java.

\section{IMPLEMENTATION METHOD}

The stages of the implementation of this service program are concisely in the form of a series of continuous activities. The implementation consists of three major stages which include preparation, implementation and evaluation which in each process has feedback from the FGD results. What continues to be carried out within the stipulated period. Stages of the implementation of this service program include: 
- Coordinating with partners regarding the implementation of PKM

- Analyze and collect data related to partner issues

- Conduct socialization and counseling on production and financial management processes

- Make improvements to improve the production process

- Implementing an E-Commerce website system for each partner

- Carry out socialization and counseling on the use of information technology and use of ECommerce website systems to support marketing.

- Make assistance efforts so that the implementation of training materials can run effectively and can be absorbed by partners, especially the use of technology and production.

- Monitoring, to monitor the extent to which these devices have been used by partners to assist the production process and increase results.

- Making reports as a form of accountability for executors in PKM activities.

For this data is a cross-section where the data sampling process is carried out at a specified time period. As the object used in this study is the UMKM partner who is a bag craftsman in Gresik. This community has similarities demographically and is in certain regions. So that it can be used as a sample for the area.

The results of the publication of Hari (Hari \& Dewi, 2018) state that this sample must be able to represent a population group in the region, as well as the results of this sampling can characteristically be applied widely to the population. The sample in this study came from craftsmen from partner UMKM in Gresik. The sample taken is considered able to represent most of the existing population. In general, samples that have the same conditions and characteristics, where they are craftsmen and originated in certain regions.

The technique for sampling in this study refers to Proportional Random Sampling. Where samples are taken randomly but based on certain proportions (Hari \& Yanggah, 2016). The sample is grouped in general based on the level of education, namely higher education, high school or equivalent and below. Then the age range taken is in the productive age range.

In this questionnaire presented with a Likert scale with intervals between 1 to 5 . With the rating scale as follows: Strongly disagree given a value of 1, Disagree was given a value of 2, Agree was given a value of 3 , strongly agree to be rated 4 , strongly agree once given a value of 5 Utilization of this scale to determine the degree of value of each response given by the respondent.

Validity test is used to measure the accuracy and accuracy of a measuring instrument. Validity test here is used to test the validity of a questionnaire. A questionnaire is declared valid if it is able to measure what is desired by the researcher in the questionnaire measurement. This validity is shown by measuring the correlation of each question variable with the total value of the variable. Where the total variable value is the sum of several factors and variables. The correlation testing process refers to the product moment correlation formula.

\section{Result of the Community Service}

\section{RESULT AND DISCUSSION}

Based on the results of the questionnaire and feedback analysis that has been carried out, the results of the research can be explained. The results can then be simplified into a graph of measurements that can be presented as in Figure 1 below. 


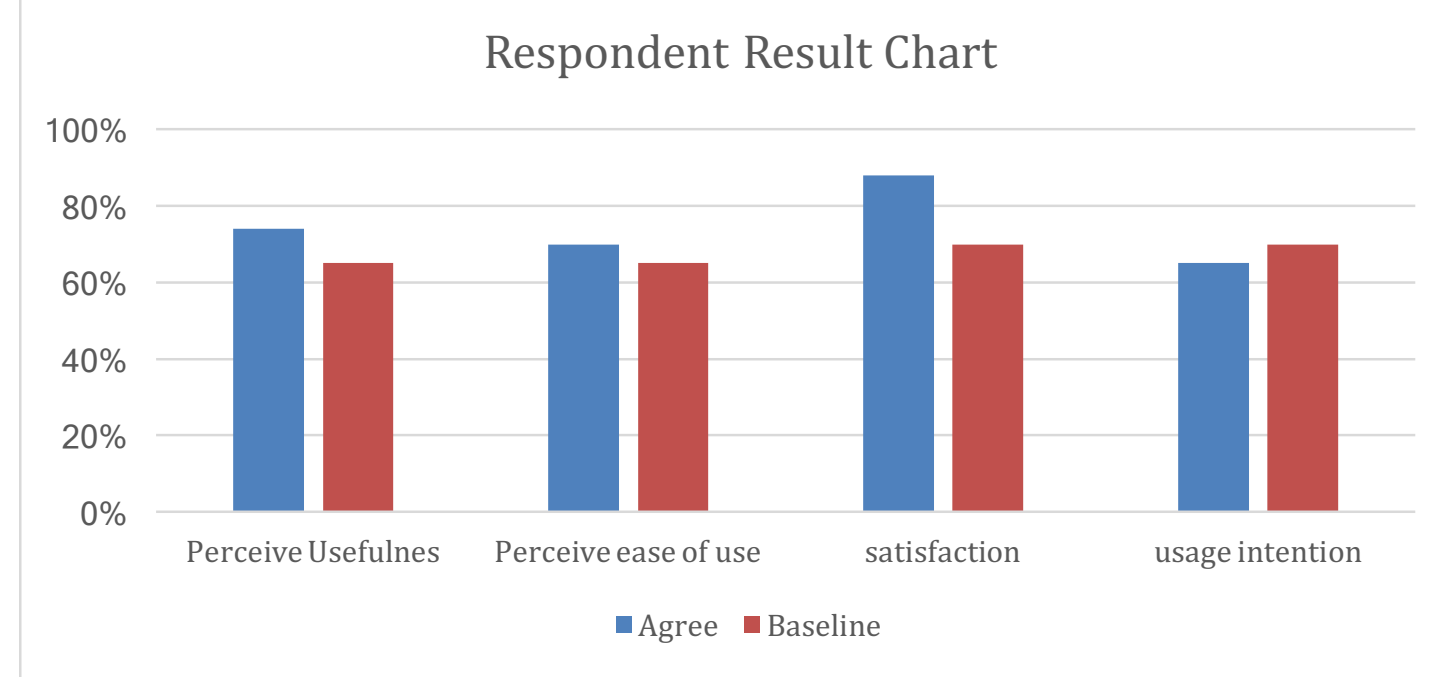

Fig 1. Respondent Result

from these results it can be seen that partners are still having difficulty using technology. then it can be concluded several things as follows. The implications of the use of technology cannot be adopted or accepted equally by all people, especially those born before the digital era, or living in rural settlements. This can be seen from their difficulties in using and understanding the process of using e-commerce technology. Both e-commerce systems can be an alternative for sales and media promotion for partners, but it will not necessarily replace what is currently available, partners still prefer brick-and-mortar models compared to click-and-dot-com business models. This is in line with what was conveyed in Cheung's research (Cheung \& Vogel, 2013) and Rahayu (Rahayu \& Day, 2015).

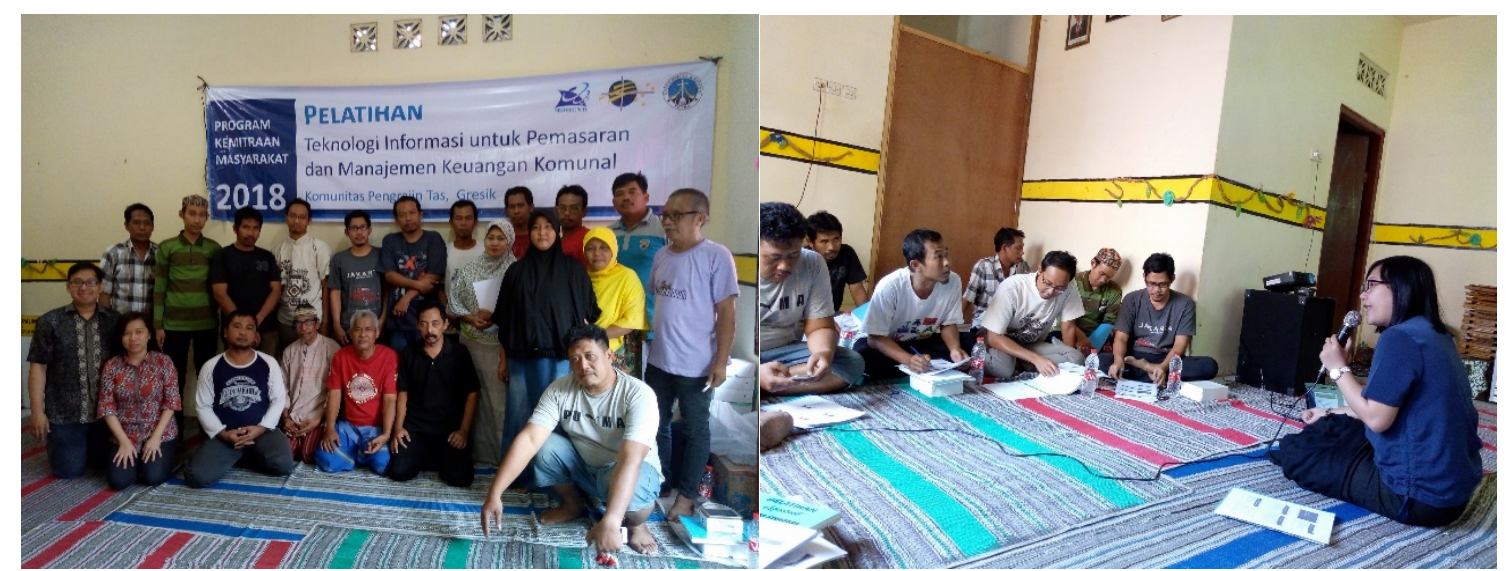

Fig 2. Training documentation in SMEs

Finally, regardless of the obstacles faced, partners are enthusiastically able to feel satisfied and want to use it again, so that this process can be mediated continuously so that the disparity in technological adaptability can be minimized.

\section{References}

Cheung, R., \& Vogel, D. (2013). Predicting user acceptance of collaborative technologies: An extension of the technology acceptance model for e-learning. Computers \& Education, 63, 160-175.

Collins, C. J., \& Smith, K. G. (2006). Knowledge exchange and combination: The role of human resource practices in the performance of high-technology firms. Academy of Management Journal, 49(3), 544-560.

Hari, Y., \& Dewi, L. P. (2018). Forecasting System Approach for Stock Trading with Relative Strength Index and Moving Average Indicator. Journal of Telecommunication, Electronic and Computer Engineering (JTEC), 10(2-3), 25-29. 
Hari, Y., \& Yanggah, M. E. (2016). Tingkat Adopsi Inovasi Teknologi Sistem M-learning Dalam Pembelajaran Bahasa Mandarin Pada Tingkat SMA. Proceeding SENDI_U.

Hashim, J. (2015). Information communication technology (ICT) adoption among SME owners in Malaysia. International Journal of Business and Information, 2(2).

Islami, A. C., Kunaifi, A., \& Gunawan, J. (2017). Ragam Pengukuran Kinerja pada Usaha Mikro, Kecil, dan Menengah (UMKM) di Surabaya. Jurnal Sains Dan Seni ITS, 6(2), D168-D171.

Jewer, J., Compeau, D., \& Besworth, M. (2017). Understanding IS Adoption and Success: Integration of IS Success and Technology Adoption Research.

Maruping, L. M., Bala, H., Venkatesh, V., \& Brown, S. A. (2017). Going beyond intention: Integrating behavioral expectation into the unified theory of acceptance and use of technology. Journal of the Association for Information Science and Technology, 68(3), 623-637.

Pentina, I., Koh, A. C., \& Le, T. T. (2012). Adoption of social networks marketing by SMEs: exploring the role of social influences and experience in technology acceptance. International Journal of Internet Marketing and Advertising, 7(1), 65-82.

Porter, C. E., \& Donthu, N. (2006). Using the technology acceptance model to explain how attitudes determine Internet usage: The role of perceived access barriers and demographics. Journal of Business Research, 59(9), 9991007.

Rahayu, R., \& Day, J. (2015). Determinant factors of e-commerce adoption by SMEs in developing country: evidence from Indonesia. Procedia-Social and Behavioral Sciences, 195, 142-150.

Stieninger, M., \& Nedbal, D. (2014). Diffusion and acceptance of cloud computing in SMEs: towards a valence model of relevant factors. In System Sciences (HICSS), 2014 47th Hawaii International Conference on (pp. 33073316). IEEE.

Tang, D., \& Chen, L. (2011). A review of the evolution of research on information Technology Acceptance Model. In Business Management and Electronic Information (BMEI), 2011 International Conference on (Vol. 2, pp. 588591). IEEE.

Timur, D. P. J. (2016). Data Pertumbuhan Industri di Wilayah Jawa Timur.

Venkatesh, V., Thong, J. Y. L., \& Xu, X. (2012). Consumer acceptance and use of information technology: extending the unified theory of acceptance and use of technology. MIS Quarterly, 157-178. 